\title{
Transformation trend of the institution of family. Family as a value, expectations, family policy
}

\author{
R. Silinsh ${ }^{1}$ and A. Martyniuk ${ }^{2}$ \\ ${ }^{1}$ Ivano-Frankivsk National Medical University, Ivano-Frankivsk, Ukraine \\ ${ }^{2}$ Vasyl Stefanyk Precarpathian National University, Ivano-Frankivsk, Ukraine
}

\begin{abstract}
This paper is devoted to the transformation trend of the institution of family which has not been deeply studied yet, and no proper attention has been paid to modern changes that have such an essential influence on the future of the family and our future in general. That is why the main aim of the research is to find out, on the basis of statistics, what factors influenced the transformation trend of the institution of family, and led to a reassessment of family values, what role is played by the state in forming the family policy, what are the future prospects for the institution of family. The results of our survey showed that the demographic situation in both countries Ukraine and Latvia needs improvement and we made up our own plan how to do it; we found what influenced the transformation trend of the institution of family; what are the values of modern families and changes related to them; compared the family policies of both countries and found out that the traditional family is under threat of disappearance. Our research proves that family is one of the most important values, whose stability and success are a guarantee of social welfare.
\end{abstract}

\section{Introduction}

In recent few years there has appeared an obvious and growing tendency for changes of the institution of family. Those changes touch upon everything that concerns family, its values and relations, family household, and affect children who like a sponge absorb everything and are sensitive to their environment in the family.

According to Robert Cliquet and his "Major trends affecting families in the new millennium. Western Europe and North America" we can observe the following changes: smaller household sizes, a further shift from extended to nuclear families, a decrease in nuptiality and an increase in separation or divorce, the appearance of new forms of unions such as unmarried cohabitation and living-apart-together, changing gender and intergenerational relations, and, last but not least, a substantial decrease in fertility, often to below-replacement levels $(1 ; 1)$. These changes deeply reflect on our youth who become like a hostage of modern transformations.

While working with growing generation and students we noticed that young people hurry to live like adults, but unfortunately not all of them understand all the seriousness of family relations and duties. Youth immediately wants to find their love, and almost every young girl or boy have their first intercourse at school. At the same time they are not physically, mentally and psychologically ready for serious relations, creating a family and taking responsibility for their relations. 
Table 1. Population in Ukraine and Latvia (2004-2014).

\begin{tabular}{|c|c|c|}
\hline $\begin{array}{c}\text { Population (at beginning mln } \\
\text { of period), mln }\end{array}$ & Ukraine & Latvia \\
\hline \hline 2004 & $47,622.4$ & $2,276.5$ \\
\hline 2005 & $47,280.8$ & $2,249.7$ \\
\hline 2006 & $46,929.5$ & $2,227.9$ \\
\hline 2007 & $46,646.0$ & $2,208.8$ \\
\hline 2008 & $46,372.7$ & $2,191.8$ \\
\hline 2009 & $46,143.7$ & $2,162.8$ \\
\hline 2010 & $45,962.9$ & $2,120.5$ \\
\hline 2011 & $45,778.5$ & $2,074.6$ \\
\hline 2012 & $45,633.6$ & $2,044.8$ \\
\hline 2013 & $45,553.0$ & $2,023.8$ \\
\hline 2014 & $45,426.2$ & $2,001.5 / 1,99$ \\
\hline & & \\
\hline
\end{tabular}

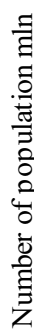

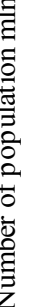

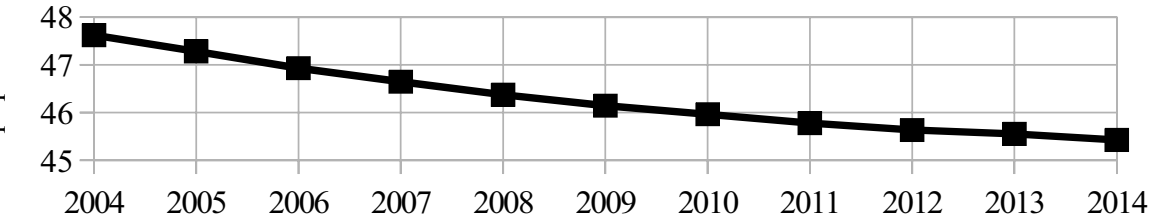

Years

Figure 1. Population in Ukraine (2004-2014) [2].

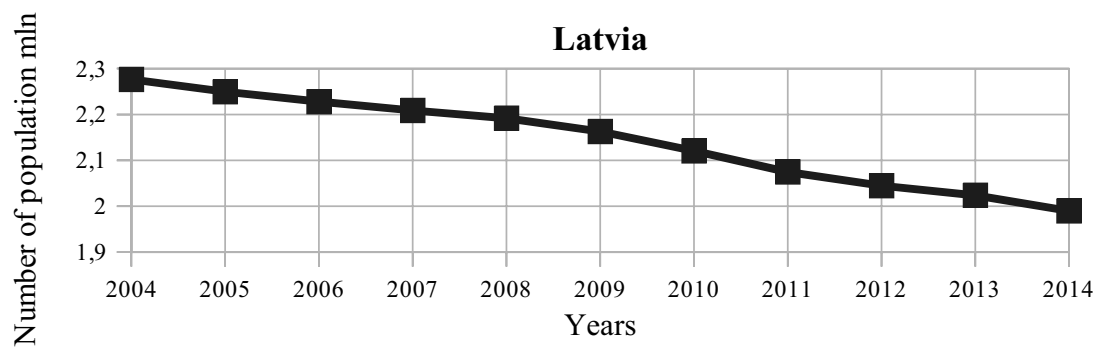

Figure 2. Population in Latvia (2004-2014) [3].

\section{The demographic situation of Ukraine and Latvia}

Having analyzed the population census in Ukraine and Latvia of the last 10 years, we got to know that the demographic situation in both countries is almost similar. Both in Ukraine and Latvia, the population has a decreasing tendency (Table 1, Figs. 1 and 2).

In 2004, the population of Ukraine consisted of 47,622.4 people, while, this year, there were only $45,426.2$ people. During the last 10 years, the population of Ukraine decreased by 2,196.2 people which equals $4.61 \%$ of the level of 2004 (Fig. 1).

As to the birth and death rates in Ukraine (Fig. 3), we can admit that within the last 10 years the number of births has raised from 427.3 thousand in 2004 to 503.7 thousand in 2013.

Although there is no natural increase in Ukraine, at the same time there is a positive side as well: negative rates have decreased 2,1 times: from -334.0 thsd. in 2004 to $-158,7$ thsd. in 2013. We think that it is a good indicator, and if this tendency continues, we will have a 


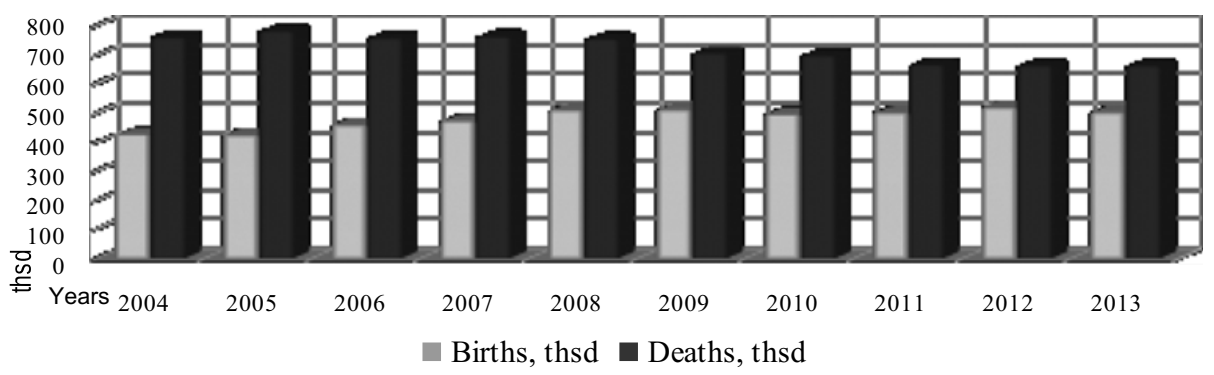

Figure 3. Births and deaths rates in Ukraine (2004-2013) [2].

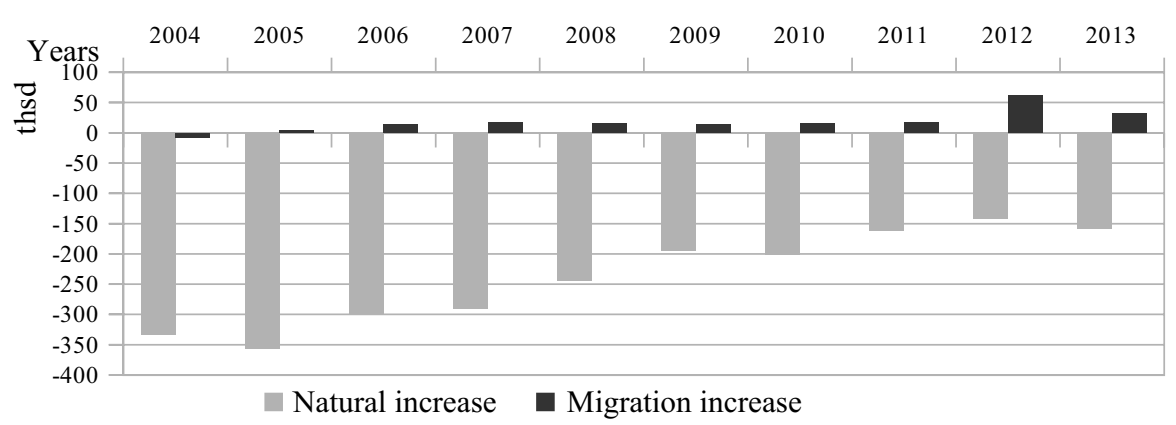

Figure 4. Natural and Migration increase in Ukraine (2004-2013) [2].

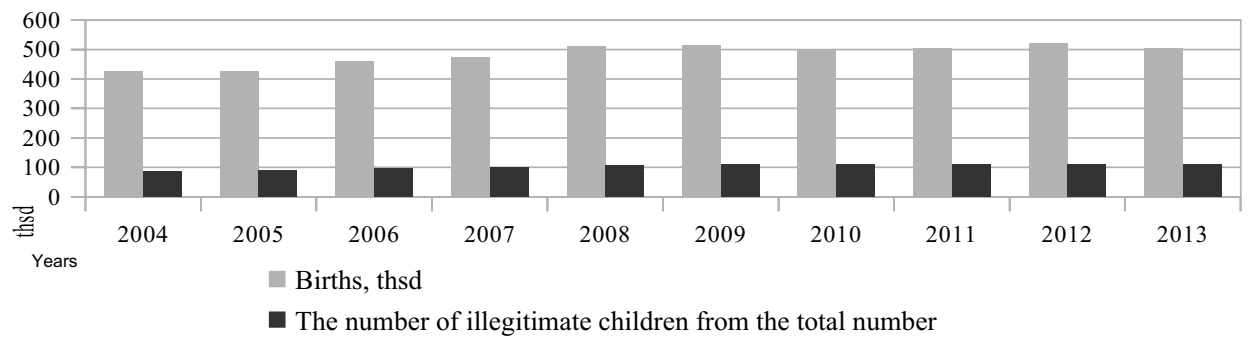

Figure 5. Ratio of extra-marital births to total births in Ukraine (2004-2013) [2].

positive natural increase in several years. The migration increase also gives us a hope: from -7.6 thsd. in 2004 to 31.9 thsd. in 2013 (Fig. 4).

There are only two sad facts: firstly, the number of illegitimate children has increased: in $2004-20.4 \%$ of the total number of births, while in $2013-22.1 \%$ (Fig. 5).

Secondly, the marriage and divorce rates are upsetting. During the period of the research, the number of divorces has amounted to $51.55 \%$ from the total marriages rate in average. The only good fact is that the percentage of divorces has decreased if compared to the situation 10 years ago: from 62.26\% in 2004 to 54.21\% in 2013 (Fig. 6). However, it is still very sad and tragic, because statistics shows us that a half or more marriages are being destroyed.

Speaking about the Latvia, the demographic situation is not much better than in Ukraine. The population census shows us the following: See the Table 3 and the Figs. 7-10. 
Table 2. Demographic situation of Ukraine* (2004-2013) [2].

\begin{tabular}{|c|c|c|c|c|c|c|c|c|c|}
\hline \multirow[t]{2}{*}{ Years } & \multirow[t]{2}{*}{ Births thsd. } & \multicolumn{2}{|c|}{$\begin{array}{l}\text { The number of } \\
\text { illegitimate children } \\
\text { from the total } \\
\text { number of birth in: }\end{array}$} & \multirow[t]{2}{*}{$\begin{array}{c}\text { Deaths } \\
\text { thsd. }\end{array}$} & \multirow[t]{2}{*}{$\begin{array}{c}\text { Natural } \\
\text { increase } \\
\text { thsd. }\end{array}$} & \multirow[t]{2}{*}{$\begin{array}{c}\text { Migration } \\
\text { increase } \\
\text { thsd. }\end{array}$} & \multirow[t]{2}{*}{$\begin{array}{c}\text { Marriages } \\
\text { - total } \\
\text { thsd. }\end{array}$} & \multicolumn{2}{|c|}{ Divorces-total thsd. } \\
\hline & & $\%$ & thsd & & & & & total thsd. & $\begin{array}{l}\% \text { from the } \\
\text { total number } \\
\text { of marriages }\end{array}$ \\
\hline 2004 & 427,3 & 20.4 & 87,1692 & 761,3 & $-334,0$ & $-7,6$ & 278,2 & 173,2 & 62.26 \\
\hline 2005 & 426,1 & 21.4 & 91,1854 & 782,0 & $-355,9$ & 4,6 & 332,1 & 183,5 & 55.25 \\
\hline 2006 & 460,4 & 21.1 & 97,1444 & 758,1 & $-297,7$ & 14,2 & 355,0 & 179,1 & 50.45 \\
\hline 2007 & 472,7 & 21.4 & 101,1578 & 762,9 & $-290,2$ & 16,8 & 416,4 & 178,4 & 42.84 \\
\hline 2008 & 510,6 & 20.9 & 106,7154 & 754,5 & $-243,9$ & 14,9 & 322,0 & 166,8 & 51.80 \\
\hline 2009 & 512,5 & 21.2 & 108,65 & 706,7 & $-194,2$ & 13,4 & 318,2 & 145,4 & 45.69 \\
\hline 2010 & 497,7 & 21.9 & 108,9963 & 698,2 & $-200,5$ & 16,1 & 305,9 & $126,1^{* *}$ & 41.22 \\
\hline 2011 & 502,6 & 21.9 & 110,0694 & 664,6 & $-162,0$ & 17,1 & 355,9 & 182,5 & 51.28 \\
\hline 2012 & 520,7 & 21.4 & 111,4298 & 663,1 & $-142,4$ & 61,8 & 278,3 & 168,5 & 60.55 \\
\hline 2013 & 503,7 & 22.1 & 111,3177 & 662,4 & $-158,7$ & 31,9 & 304,2 & 164,9 & 54.21 \\
\hline
\end{tabular}

*All data are taken from the State Statistics Service of Ukraine [2].

Table 3. Demographic situation of Latvia (2004-2013) [3].

\begin{tabular}{|c|c|c|c|c|c|c|c|c|}
\hline Years & $\begin{array}{c}\text { Births } \\
\text { total } \\
\text { thsd. }\end{array}$ & $\begin{array}{c}\text { The number of } \\
\text { illegitimate children } \\
\text { from the total number } \\
\text { of birth in: }\end{array}$ & $\begin{array}{c}\text { Deaths } \\
\text { thsd. }\end{array}$ & $\begin{array}{c}\text { Natural } \\
\text { increase } \\
\text { thsd. }\end{array}$ & $\begin{array}{c}\text { Net } \\
\text { migration } \\
\text { thsd. }\end{array}$ & $\begin{array}{c}\text { Marriages } \\
\text { total thsd. }\end{array}$ & $\begin{array}{c}\text { Divorces - } \\
\text { total thsd. }\end{array}$ \\
\cline { 3 - 8 } & & thsd. & & & & & \\
\hline 2004 & 20,551 & 45.31 & 9,312 & 32,024 & $-11,473$ & $-15,323$ & 10,370 & 5,271 \\
\hline 2005 & 21,879 & 44.73 & 9,786 & 32,777 & $-10,898$ & $-10,952$ & 12,544 & 6,341 \\
\hline 2006 & 22,871 & 43.79 & 10,016 & 33,098 & $-10,227$ & $-8,807$ & 14,616 & 7,249 \\
\hline 2007 & 23,958 & 43.23 & 10,357 & 33,042 & $-9,084$ & $-7,946$ & 15,486 & 7,403 \\
\hline 2008 & 24,397 & 43.22 & 10,544 & 31,006 & $-6,609$ & $-22,367$ & 12,946 & 6,214 \\
\hline 2009 & 22,044 & 43.51 & 9,592 & 29,897 & $-7,853$ & $-34,477$ & 9,925 & 5,099 \\
\hline 2010 & 19,781 & 44.37 & 8,777 & 30,040 & $-10,259$ & $-35,640$ & 9,290 & 4,930 \\
\hline 2011 & 18,825 & 44.57 & 8,390 & 28,540 & $-9,715$ & $-20,077$ & 10,760 & 8,302 \\
\hline 2012 & 19,897 & 44.99 & 8,951 & 29,025 & $-9,128$ & $-11,860$ & 11,244 & 7,311 \\
\hline 2013 & 20,596 & 44.62 & 9,190 & 28,691 & $-8,095$ & $-14,262$ & 11,436 & 7,031 \\
\hline
\end{tabular}

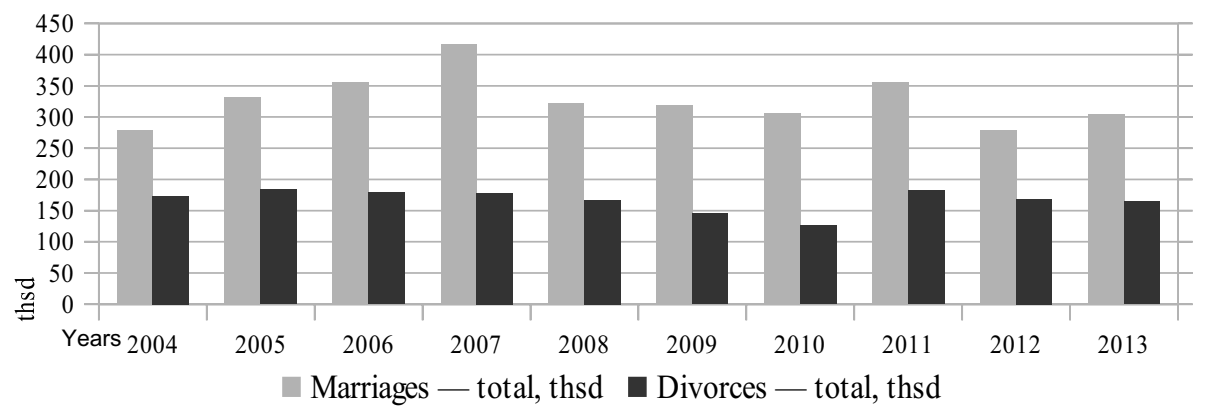

Figure 6. Marriages/Divorces rates in Ukraine (2004-2013) [2]. 


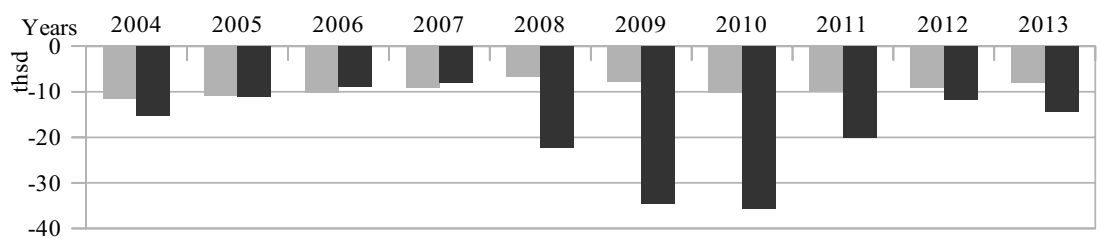

Natural increase, thsd $\quad$ Net migration, thsd

Figure 7. Natural increase and Net Migration in Latvia (2004-2013) [3].

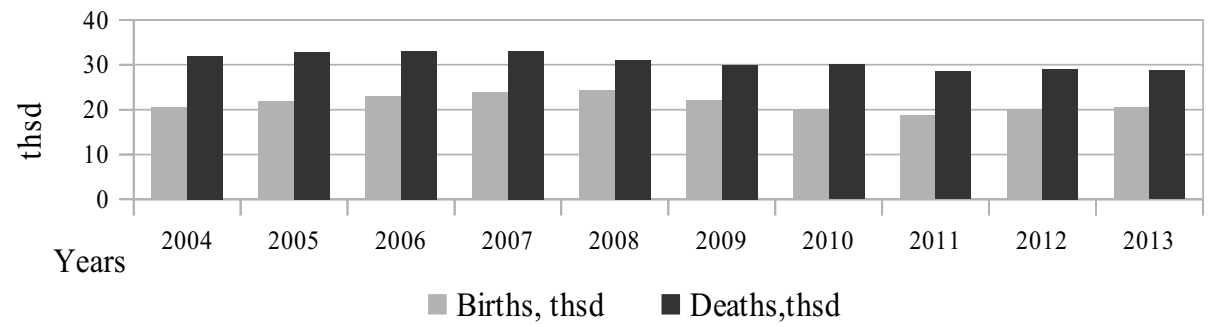

Figure 8. Birth/Death rates in Latvia (2004-2013) [3].

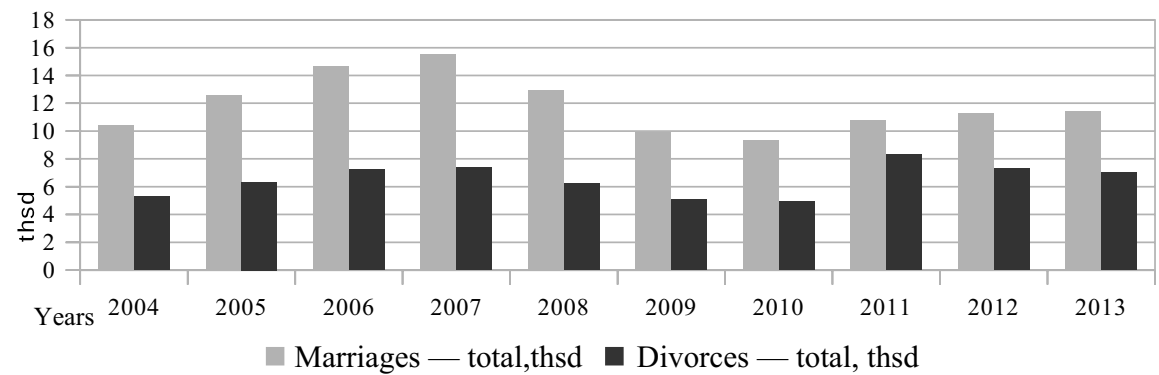

Figure 9. Marriages/Divorces rates in Latvia (2004-2013) [3].

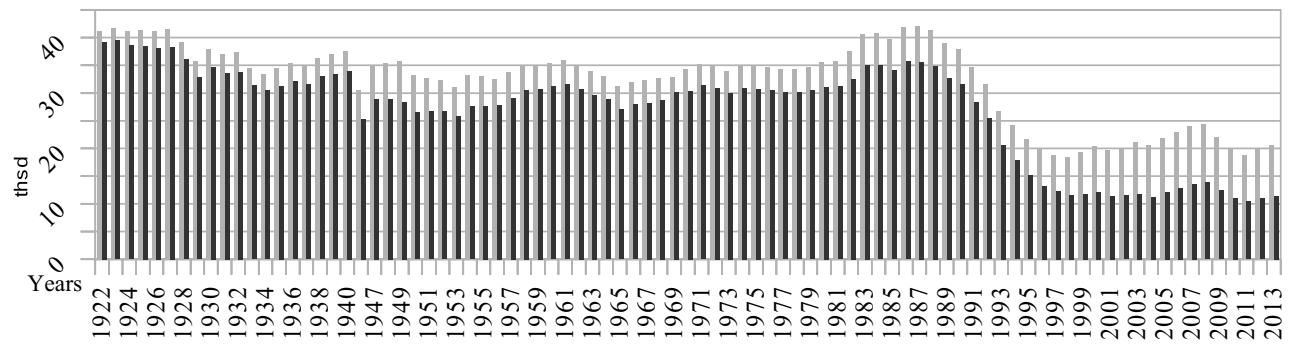

Live births $\square$ Ratio of marital births to total live births

Figure 10. Ratio of marital births to total live births in Latvia (1922-2013) [3]. 


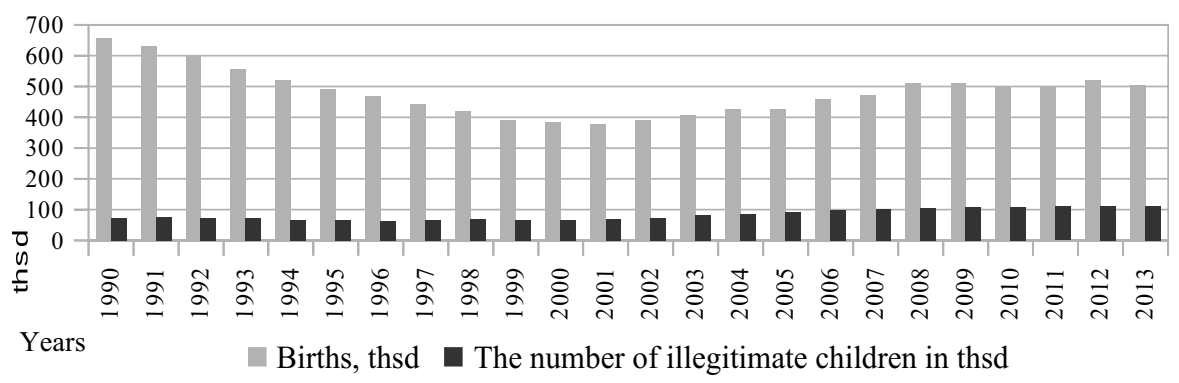

Figure 11. Ratio of extra-marital births to total births in Ukraine (1990-2013) [2].

According to the data of the Central Statistical Bureau of Latvia, unfortunately, there is no natural increase in Latvia; there is only positive feature: the negative tendency has decreased from $-11,473$ to $-8,095$ (Fig. 7).

However, it did not happen because of increasing birth rates, but due to decreasing death rates: 32.024 thsd. in 2004 and 28.691 thsd. in 2013 (Fig. 8).

From our point of view, it is the medicine that has helped to reach such indicators. The Medicine is constantly developing, and becoming more progressive in finding new medicines and new ways of treatment of severe diseases. The achievements of the contemporary medicine, high level of medical services, highly qualified medical specialists here in Latvia it all gives us an opportunity to extend the lifetime, especially for older persons.

It is good, but at the same time, when the number of retired people is increasing while the birth rates are not, and when the net migration is $-14,262$ (Figs. 7 and 8), it is necessary to take urgent measures in order to improve such demographic situation. There is also a sad situation in relation to marriage/divorce rates (Fig. 9).

The average number of divorces is approximately $55.48 \%$ of the total number of marriages, and the extra-marital birth rates are also very high, i.e. $44.23 \%$ - in average for the last 10 years.

Comparison of approximately 88 years old marriage/divorce rates and the number of illegitimate children (compared to the total number of birth) with the contemporary data, shows one very interesting tendency. At that time in Latvia the level of divorces and extramarital birth rates were very low, the number of divorces began to increase starting from 1960-s, the number of illegitimate children - from 2000 (Figs. 9 and 10) [3].

We could find data on Ukraine only starting from 1990-s, and, even 24 years ago, the number of children born in unregistered marriage was twice lower than now, see Fig. 11 [2].

Although we do not have 80-50 year old data about Ukraine, we can state that the situation was much better many years ago. We know this from the stories of our grandmothers. At those hard times, even war times, no one ever thought of divorce or abortion, contrary to the modern tendency.

\section{Plan for improvement of demographic situation}

Why do you think we have such sad statistics? What has happened to our society? How to improve this situation?

We, young researchers, propose a plan to make the situation better:

Step 1. Provide young specialists who have graduated from universities with stable jobs and competitive salaries. 
Step 2. Raise the salaries of teachers of all levels and educational establishments, as well as the salaries of all doctors in order to stop the emigration of qualified specialists.

Step 3. Create a system of credits friendly to young families with the aim of buying their own apartment.

Step 4. Raise the level of morality in schools, (especially in medical universities among teachers and medical students, among doctors and doctors-gynecologists, prenatal specialists, whose prerogative should be the slogan - "Save the person's life by all means, particularly the life of an unborn child").

Step 5. Introduce new disciplines in the above mentioned establishments (such as the psychology of relationship between boys and girls, men and women, the psychology of building family relationships, the ethics of marital life, the negative influence of early sex relations, premarital sex, abortion and divorces on the future family) [4].

Step 6. The state should censor TV programs and mass media and prohibit the scenes of crimes, violence, sex and sex perversions, unhealthy sex relations.

Step 7. Improve the family policy, by not only paying money after a child's birth, but also by taking real measures in supporting families.

Step 8. Parents should also pay attention to their children and limit the children's access to all negative information and the Internet.

\section{Modern transformations of the family institution}

According to Robert Cliquet the transformation trend of the institution of family finds reflexion in such changes as the relational behaviour, the reproductive behaviour, intergenerational relations, the HIV/AIDS pandemic, increasing migration, the impact of globalization and the changes, which we mentioned at the beginning of our research [1]; 2, 8, 12, 18, 19, 22. We agree with Robert Cliquet and his classification of these changes.

But at the same time we want to add our own list of modern transformations not only of the institution of family and its basic principles, but also of the transformations of human's souls, particularly the children's souls. And this is the worst. Maybe you have noticed how much our children differ from us, adults. They are more aware, sometimes well-informed in such questions, which we are ashamed to speak about and at their age we never thought about. Altogether we can admit the increasing level of cruelty and violence, aggression among schoolchildren and youth.

From our point of view such factors as

- Ignoring the moral values, traditions, God and 10 God's Commandments;

- propaganda of early sex relations, premarital sex, and gender equality [5];

- distorted understanding of the concepts "family", "family values", "marriage", "father", and "mother";

- neglecting the essential role of both parents in the upbringing of children,

- easy access to the Internet and films with scenes of violence crimes, and porno films;

- high abortion rate and propaganda of abortions.

are the changes which affect the demographic situation we have today. These very factors are the main reasons why most young people are not ready for family relationships or do not know how to keep already created families. 


\section{Family values}

With great sadness we notice that contemporary world gives a challenge to a traditional family and family values. Family is not only a union of two people but also a social institution which stems from the need of society in the physical and spiritual reproduction. Family acts as a social cell of society, very close to the "original" model of the society in which it operates [6].

Family values are: marriage, children, love, mutual understanding and respect, ability to find compromises. Unfortunately, at present these values are ignored in the best case, and are exterminated in the worst case. Low rate of fertility, high divorce rate, increasing number of illegitimate children, high abortion rate and so on are the "bright" examples of our "nowadays values".

Family, as well as children, is God's great gift. Do you think if you have a family or children, it is your merit? No, my dear, you are mistaken. This is the present of God to you [5].

Talking about the marriage and the possibility of divorce, we should appeal to the most reliable source - The Holy Bible, to The Holy Gospel of Jesus Christ. According to St. Mark: "And the Pharisees coming to him asked him: Is it lawful for a man to put away his wife? tempting him. But he answering, saith to them: What did Moses command you? Who said: Moses permitted to write a bill of divorce, and to put her away. To whom Jesus answering, said: Because of the hardness of your heart he wrote you that precept. But from the beginning of the creation, God made them male and female. For this cause a man shall leave his father and mother; and shall cleave to his wife. And they two shall be in one flesh. Therefore now they are not two, but one flesh. What therefore God hath joined together, let not man put asunder. And in the house again his disciples asked him concerning the same thing. And he saith to them: Whosoever shall put away his wife and marry another, committeth adultery against her. And if the wife shall put away her husband, and be married to another, she committeth adultery" [7]; [Part 10:3-12].

The words of our God, Jesus Christ about children: "And they brought to him young children, that he might touch them. And the disciples rebuked them that brought them. Whom when Jesus saw, he was much displeased, and saith to them: Suffer the little children to come unto me, and forbid them not; for of such is the kingdom of God. Amen I say to you, whosoever shall not receive the kingdom of God as a little child, shall not enter into it. And embracing them, and laying his hands upon them, he blessed them" [7]; According to St. Mark, [10:1316]. These words teach parents to educate their children properly in order to get the eternal life and show us that children are holy in a metaphorical meaning. That is why our parent's duty is to protect our children from all bad influences and negative information.

Some nice statements about the sense of life:

"We live on Earth with the goal to mature for eternal life, to learn to love"(With the revelation of the Virgin in Chivitavek'ya) [8].

"A happy marriage is the union of two good forgivers." (Ruth Bell Graham) [8].

"Dirty with the earth wealth, a human very weakly understands the truth, and unfortunately, loves that, what should hates, and hates that, what should love" [9]; 7. This statement is taken from the prayer book to the Holy Spirit and very vividly demonstrates our contemporary morality, and underlines the real sense of divorce and marital faithfulness.

\section{Family Policy}

Passing over to the family policy, we want to say that the state forms the family policy. The term "family policy" usually relates to social programs, legislation and regulations that are 
intended to promote growth in the number of families, increase fertility and child-rearing. And the state also bears its own responsibility for family welfare towards society [10].

\section{Policy Objectives and Basic Principles of Latvia}

The overarching objective of the State family policy is to promote the starting of families and their stability, to increase birth rates and to strengthen the institution of marriage and its value in the society.

The overarching objective is specified in the objective of each line of action (see Chapter 4 "Lines and Tasks of Action"). The basic principles of making the State family policy that are essential while preparing policy documents in any family related field are the following:

Principle of family as a social and economic value: to contribute significantly to the State's ability to provide its inhabitants with the rights specified in the Constitution and other laws and regulations;

Principle of planning a family-friendly State development: public sector policies are planned to promote creation of social and economic conditions that would comply with the needs and interests of families and that would contribute to higher birth rates as a prerequisite for a long-term development and stability of the State;

Principle of support corresponding to family needs: the State and municipalities, while developing a support system for families, ensure its availability at all important moments depending on situation and needs of the family;

Principle stating that large families are an important value: the State and municipalities provide a particular support to large families.

Principle of priority of the child's rights and interests: all public and private persons (both natural and legal) act in line with the child's best interests;

Principle of availability of information and services provided by public or local authorities: provision of families and young people with information corresponding with their needs and interests, as well as convenient and available provision of relevant services, such as reduction of administrative burden when requesting these services and when ensuring possibility of electronic request and receipt of such services;

Principle of equality between parents: both parents have equal rights to participate in the child care process and to prove themselves professionally;

Principle of parental responsibility: parents are obliged to take care of their child and to ensure living conditions favorable for the child's physical and intellectual development, or to cover costs related to the child's extra-familial care if the parents do not meet their obligations towards the child to an appropriate extent[11]; 7.

For implementation of the State family policy, on May 28, 2002, the Cabinet of Ministers (CM) approved the concept "The State Family Policy" and this Concept still remains in force. However, eight years have passed since the approval of the Concept and both society and economy have experienced significant changes creating necessity for an updated policy planning document that would comply with the Guidelines for the Development of Policy Planning System (Order No. 705 of 18/09/2006 by the CM), which after their entry into force, will replace the Concept and will undertake its lines and tasks of action. The Guidelines is a medium-term policy planning document for the next 7 years defining the overarching objective, lines of action, their objectives, policy results and performance indicators [11]; 5 . The Guidelines were set basing on the so-called family life-cycle approach. The situation description is organized in correspondence with its stages by assigning the most important 
Table 4. Child Birth Benefit in Ukraine (1.12.2013-till nowadays).

\begin{tabular}{|c|c|c|}
\hline Child Birth Benefit & From 1.12.2013- & $\begin{array}{c}\text { From 1.07.2014 } \\
\text { (UAH) }\end{array}$ \\
\hline First child (the total sum) & $\mathbf{3 0} 06.2014(\mathrm{UAH})$ & $\mathbf{4 1 ~ 2 8 0}$ \\
\hline First payment & 10320 & 10320 \\
monthly payment & 860 & 860 \\
\hline Second child (the total sum) & $\mathbf{6 1 9 2 0}$ & $\mathbf{4 1 ~ 2 8 0}$ \\
\hline First payment & 10320 & 10320 \\
monthly payment & 1075 & 860 \\
\hline Third child (the total sum) & $\mathbf{1 2 3 8 4 0}$ & $\mathbf{4 1 ~ 2 8 0}$ \\
\hline First payment & 10320 & 10320 \\
monthly payment & 1576,67 & 860 \\
\hline
\end{tabular}

role to the family as the basic element of the society: Marriage, starting a family; Family life planning; Child's arrival in the family; Upbringing and care of the child; Achieving a psychological maturity, value-oriented beginning of independent life [11]; 6.

\section{One of the directions of family policy in Latvia is the integration of immigrants in Latvia:}

1. Issuance of residence permits and reunification of families;

2. Development of housing policy for immigrants;

3. Availability of labor market: work permit;

4. Acquiring knowledge of national language and qualification for work in Latvia;

5. Integrated learning of the history of Latvia;

6. Education of children of the immigrants [12]; [37-53].

In fact, the real help from the state comes in the form of benefits: Maternity Benefit, Paternity Benefit, Child Birth Benefit, Parents' Benefit, Family State Benefit, Disabled Child Care Benefit, State support to the children suffering from Celiac Disease, Foster family allowance, Custody, Survivors' benefits (Pension in Case of Loss of Supporter), Funeral Allowance, Adoption Benefit [13].

\section{The Family Policy of Ukraine}

The Ukrainian family policy has similar Basic Principles to those in Latvia, which are defined in the Ukrainian Constitution. To avoid repetition we just add that the main instrument of family policy in Ukraine is a benefit after a child was born [14]. See Table 4.

The benefit at birth (the order is valid until 01/07/2014) is paid at a rate that depends on the number of children in the family - the first, second, third ..., also the sum depends on your date of birth (Law of Ukraine "On State Budget of Ukraine for 2014"). Starting from the 01/07/2014 according to the Law of Ukraine "On prevention of financial disaster and creating conditions for economic growth in Ukraine"), the amount of help at birth will not depend on whether the first, second, third child in the family was born . Maternity benefit is granted in the amount of $41280 \mathrm{UAH}$ [15].

Comparing the family policies of both countries, we want to admit that in Ukraine our policy is very loyal to families and we can get a good support in the case of need.

About immigrants. The environment for integration is not complicated by work permit; acquiring knowledge of national language and qualification for work in Ukraine; integrated learning of the history of Ukraine. 


\section{Future prospects}

We made sure that the family expectations depend on the direction in which the family policy and social morality move. The multiplication of family forms in recent years constitutes the basis for the majority of hypotheses regarding the future of the family. According to the sources related to the issue in question (Cornish, 1979; Duvold, 1995; Roussel, 1989) mainstream 'visions of the future' can be regrouped in the following three major types of scenarios:

- (1) The disappearance of the family;

- (2) The restoration of the traditional family;

- (3) The persistence or further increase of family variation (1; 23-24).

\section{Conclusions}

Summing up the results of our research we can state that family is under threat of disappearance. And clear evidence of this is the modern family transformations. That is why we, as Christians, and people who are not indifferent to our future and our children's future should raise the alarm and do our best to save a traditional family, healthy family relations, traditional and healthy family values for the next generations. The results of our survey prove that family is one of the most important values, whose stability and success are a guarantee of social welfare according to the Chinese proverb - "When there is love in a marriage, there is harmony in the home; when there is harmony in the home, there is contentment in the community; when there is contentment in the community, there is prosperity in the nation; when there is prosperity in the nation, there is peace in the world" [16].

\section{References}

[1] Robert Cliquet, Major trends affecting families in the new millennium - Western Europe and North America. http://undesadspd.org/LinkClick.aspx?fileticket $=$ wclbstPFzJo\%3D\&HYPERLINK"

http://undesadspd.org/LinkClick.aspx?fileticket=wclbstPFzJo=\& tabid $=282$ "tabid $=282$

[2] State Statistics Service of Ukraine www .ukrstat.gov.ua

[3] Centrāāās statistikas pārvaldes http://www.csb.gov.lv/en/dati/statisticsdatabase 30501.html

[4] Слово вчителю. Етика подружнього життя. Інтерв'ю 3 Адріаном Буковинським (А word to teacher. The ethics of marital life. Interview with Adrian Bukovynski) http: //www . bukovynski.com/slovo-vchitelyu/

[5] Про шлюб і сімейне життя (About marriage and family life)/ http://www. traducionalist.info/blog/pro_shljub_i_simejne_zhittja/2015-0206-3311

[6] Шлюб та сім'я: поняття, сутність, типологія (Marriage and family: concept, essence, typology)/http://pidruchniki.com/18540516/sotsiologiya/shlyub _simya_ponyattya_sutnist_tipologiya

[7] http://triggs.djvu.org/djvu-editions.com/BIBLES/DRV/Download.pdf

[8] Christian quotations: Love/http://www.truechristianity.info/en/quot ations_love_en.php 
[9] Дари найкращі (Набоженства до Святого Духа)(The Best Gifts. Prayers to the Holy Spirit), Івано-Франківськ: Нова Зоря, 34 (1999).

[10] Постанова Верховної ради України "Про Конщепџію державної сімейної політики” http://zakon2.rada.gov.ua/laws/show/1063-14

[11] Gimenes valsts politikas pamatnostādnes 2011.-2017.gadam, 5-7/ www.1m.gov.1v/ upload/berns_gimene/bernu.../akti/gimpamatpreciz.doc/

[12] I. Ķešane, R. Kaša, Mācāmies uzņemt: Imigrantu integrācija Latvijā, Mācāmies uznnemt: Imigr. Integr. Latvijā un Polijāa, Sabiedr. Polit. centrs PROVIDUS, 37-53 (2008).

[13] http://www.vsaa.lv/en/services/parents/allowance-child-care.

[14] Law of Ukraine "On State Support to Families with Children" http://zakon1. rada.gov.ua/cgi-bin/laws/main.cgi?nreg=2811-12\&p=1270204897733506.

[15] http://www.i-law.kiev.ua/ допомога-при-народженні-дитини/

[16] Top 60 marriage quotes on the web http://www.happywivesclub.com/ top-60-marriage-quotes-on-the-web/ 